\title{
APLIKASI PATI BIJI ALPUKAT (Parcea americana. Mill) SEBAGAI EDIBLE COATING BUAH STRAWBERRY (Fragaria sp.) DENGAN PENAMBAHAN EKSTRAK JAHE (Zingiber officinale. Rosc)
}

Application of Alpukat Seeds (parcea Americana. Mill) as Edible Coaching Strawberry Fruit (fragaria $s p$ ) with Addition of Zingiber Oil (Zingiber officinale. Rosc)

\author{
Muhammad Fahmi Rangkuti, Muhammad Hafiz, Irma Julyanty Munthe, Misril Fuadi \\ Teknologi Hasil Pertanian \\ Fakultas Pertanian Universitas Muhammadiyah Sumatera Utara \\ mfahmiray2802@gmail.com
}

\begin{abstract}
This study aims to study edible coating avocado starch starch on strawberry fruit and also to know the amount of zingiber extract used in the manufacture of edible coating on avocado seeds for strawberry fruit. This study used a complete randomized design (RAL) factorial with (2) two replications. Factor I is the amount of avocado seed starch with a password (P) consisting of 4 levels: $\mathrm{P} 1=0 \%, \mathrm{P} 2=5 \%, \mathrm{P} 3=10 \%, \mathrm{P} 4=15 \%$. Factor II is the amount of addition of zingiber extract with a password (D) consisting of 4 levels ie D1 $=0 \%$, D2 $=3 \%$, D3 = 6\%, D4 = 9\%. Parameters observed included: weight loss, TSS, Vitamin C, Total Acid, color organoleptic test, organoleptic aroma, organoleptic flavor. The result of statistic analysis on each parameter gives the following conclusion: the amount of avocado seed concentration gives very significant different effect on $\mathrm{P}<0.01$ level to weight shrinkage, TSS, Vitamin C, Total Acid, color organoleptic test, and organoleptic test of flavor . While at P> 0,05 level was not significant on organolpetic test of aroma, the amount of extract of betel leaf extract had very different effect on $\mathrm{p}<0,01$ to weight shrinkage, TSS, Vitamin C, Total asam, color organoleptic test, organoleptic test of flavor. While at $p>0,05$, it was not significant to organoleptic test of aroma. And on the interaction the amount of avocado starch concentration and the addition of zingiber extract have a very significant different effect on the weight loss, Vitamin C, and total acid. And different not significant on TSS, colour organoleptic test, organoleptic test of aroma and taste organoleptic test. The best results on weight loss were P4D4 which was 0,0900\%, vitamin C was P4D4 21,130 mg / 100 gr, and total P4D4 acid 2,112\%.
\end{abstract}

Key words : Edible coating, Avocado fruit, Strawberry fruit, Zingiber extract

\section{A. PENDAHULUAN}

Kendala utama produk-produk pertanian terutama produk hortikultura adalah umur simpan yang relatif singkat serta mudah rusak (perisable), sehingga apabila produk tersebut setelah panen tidak ditangani dengan cara baik, akan mengakibatkan pengaruh negatif yang tidak menguntungkan atau merugikan secara alamiah.

Produk hortikultura mengalami perubahan-perubahan komposisi akibat pengaruh fisiologi, fisik, kimia, parasitik, atau mikrobiologi. Akibat yang sangat merugikan jika tidak dikendalikan, adalah timbulnya kerusakan atau kebusukan, yang pada akhirnya akan menurunkan kualitas bahkan kuantitas produk tersebut (Aminudin, 2010). Masalah utama strawberry adalah sifatnya yang mudah rusak oleh pengaruh mekanis dan memiliki umur simpan yang singkat. Strawberry memiliki kadar air yang tinggi sehingga mudah busuk akibat aktivitas enzim atau mikroorganisme. Tingkat kerusakan buah dipengaruhi oleh difusi gas kedalam dan keluar buah yang terjadi melalui intisel yang tersebar dipermukaan buah difusi gas tersebut secara alami dihambat dengan lapisan kulit yang sangat mudah membusuk yang dilakukan pada saat penanganan pasca panen.

Oleh karena itu diperlukan upaya untuk menambah bahan pelapis yang dapat mengurangi difusi gas. Bahan pelapis buah akan membentuk suatu lapisan yang mampu berperan sebagai pelindung kulit buah, menghambat pertukaran gas pada buah dan 
Muhammad Fahmi Rangkuti, Muhammad Hafiz, Irma Julyanty Munthe, Misril Fuadi / Agrintech | Jurnal Teknologi Pangan dan Hasil Pertanian 3 (1) 2019, 1-10

menghambat pertumbuhan bakteri (Krochta, dkk. 2002). Edible coating merupakan salah satu cara yang tepaat untuk digunakan dalam memperpanjang umur simpan buah. Komponen utama penyusun coating dapat dikelompokkan menjadi tiga kategori yaitu, hidrokoloid, lipid, dan komposit (campuran).

Hidrokoloid yang dapat digunakan untuk membuat edible coating adalah protein (gelatin, kasein, protein kedelai, protein jagung, dan gluten gandum) dan polisakarida (pati, alginat, pektin, dan midifikasi karbohidrat lainnya). Lipida yang dapat digunakan adalah lilin, gliserol dan asam lemak (Krocha, dkk, 2002). Biji buah alpukat sampai saat ini hanya dibuang sebagai limbah yang dapat menyebabkan pencemaran lingkungan. Sementara didalam biji alpukat mengandung zat pati yang cukup tinggi yakni $23 \%$. Hal

ini memungkinkan biji alpukat sebagai alternatif sumber pati. Biji alpukat yang diolah menjadi pati, selain bermanfaat mengurangi pencemaran lingkungan juga dapat di olah menjadiberbagai hasil olahan yang mempunyai nilai jual tinggi salah satunya di aplikasikan sebaga edible coating (Winarti dan Purnomo, 2006).

\section{B. BAHAN DAN METODE}

Bahan Penelitian Bahan utama yang digunakan dalam penelitian ini adalah Pati Biji Alpukat (Parcea americana Mill), Buah Strawberry (Fragaria $s p$ ), dan Jahe (Zingiber officinale Rosc).

\section{Bahan Kimia}

Bahan kimia yang digunakan dalam penelitian ini adalah Gliserol 2\%, $\mathrm{NaOH} 0,1$, Iodium 0,1 N , Indikator Fenol ftalein (PP), Indikator Amilum, Aquadest.

\section{Alat Penelitian}

Adapun peralatan yang digunakan dalam penelitian ini adalah sebagai berikut: Beaker glass $500 \mathrm{ml}$, Beaker glass $100 \mathrm{ml}$, Batang pengaduk 6 buah, Pipet tetes 2 buah, timbangan biasa, timbangan analitik, kertas saring, baskom, oven, aluminium foil, pisau, blender, nampan plastik, saringan 80 mesh, kain saring, erlemeyer, alattitrasi, mortal dan alu, refractometer .

\section{Metode Penelitian}

Model rancangan yang akan digunakan pada penelitian ini adalah model Rancangan Acak Lengkap (RAL) faktorial, yang terdiri atas dua faktor yaitu:

Faktor I : Jumlah Pati Biji Alpukat (Parcea americana Mill) yang terdiridari 4 taraf yaitu:

$$
\begin{aligned}
& \mathrm{P} 1=0 \% \\
& \mathrm{P} 3=10 \% \\
& \mathrm{P} 2=5 \% \\
& \mathrm{P} 4=15 \%
\end{aligned}
$$

Faktor II :Jumlah Penambahan Ekstrak Jahe yang terdiri dari 4 taraf yaitu :

$$
\begin{aligned}
& \text { D1 }=0 \% \\
& \text { D3 }=6 \% \\
& \text { D2 }=3 \% \\
& \text { D4 }=9 \%
\end{aligned}
$$

Banyaknya kombinasi perlakuan (Tc) adalah sebnyak $4 \times 4=16$, sehingga jumlah ulangan percobaan (n) dapat dihitung sebagia berikut :

$$
\begin{aligned}
\text { Tc }(\mathrm{n}-1) & >15 \\
16(\mathrm{n}-1) & >15 \\
16 \mathrm{n} & >31 \\
\mathrm{n} & \geq 1,937
\end{aligned}
$$

Di bulatkan menjadi $\mathrm{n}=2$ Maka untuk ketelitian penelitian, dilakukan ulangan sebnyak 2 (dua) kali.

\section{Model Rancangan Percobaan}

Penelitian ini dilakukan dengan menggunakan Rancangan Acak Lengkap (RAL) factorial dengan model linier :

$$
Y i j k=\pi+\alpha i+\beta j+(\alpha \beta) i j+€ i j k
$$

Dimana:

Yijk = Hasil pengamatan atau respon karena pengaruh factor $\mathrm{G}$ pada taraf ke -I dan factor J pada taraf ke - j dengan ulangan pada taraf ke-k

$\mu=$ Efek nilai tengah

$\alpha \mathrm{i}=$ Efek perlakuan $\mathrm{G}$ pada taraf ke- $\mathrm{i}$

$\beta \mathrm{j}=$ Efek perlakuan $\mathrm{J}$ pada taraf ke- $\mathrm{j}$

$(\alpha \beta) \mathrm{ij}=$ Efek interaksi factor $\mathrm{G}$ pada taraf ke- I dan factor J pada taraf ke-j

$€ \mathrm{ijk}=$ Efek galat dari factor $\mathrm{G}$ pada taraf ke-I dan factor J pada taraf ke -j dan ulangan pada taraf ke- $\mathrm{k}$.

Pelaksanaan Penelitian :

\section{Proses Pembuatan Pati Biji Buah} Alpukat

Pengupasan kulit biji alpukat, kemudian sortasi atau pemisahan biji dari biji yang telah rusak atau busuk, setelah 
Muhammad Fahmi Rangkuti, Muhammad Hafiz, Irma Julyanty Munthe, Misril Fuadi / Agrintech | Jurnal Teknologi Pangan dan Hasil Pertanian 3 (1) 2019, 1-10

itu pencucian dilakukan dengan menggunakan air bersih dan sebaik nya dengan air mengalir, setelah semua bersih dilakukan pengecilan ukuran dengan menggunakan pisau, penggilingan dilakukan dengan menggunakan blender. Pada proses ini ditambahkan air kira-kira 1:1 (1 kg biji ditambahkan 1 liter air).

Kemudian pemerasan dilakukan menggunakan serbet ,Setelah itu didiamkan sampai terjadinya pemisahan antara air bening dan endapan, setelah terpisah air bening dibuang secara perlahan. Endapan dikeringkan menggunakan oven dengan suhu $800 \mathrm{C}$ selama 3 jam. Kemudian setelah kering diblender dan kemudian di ayak menggunakan ayakan 80 mesh, jadilah pati biji buah alpukat.

\section{Proses Pembuatan Ekstrak Jahe}

Jahe sortasi dan cuci bersih, kemudian tiriskan dan angin-anginkan selama10 menit, lalu pisahkan ruas- ruas supaya mudah di blender dan untuk membantu pengecilan ukuran, Oven jahe dengan suhu $700 \mathrm{C}$ selama 3 jam, Blender sampai halus, campurkan 250

gr jahe kering dengan $30 \mathrm{ml}$ aquades diamkan selama 1 malam , saring menggunakan kertas saring. Tambahkan dalam edible coating pati biji alpukat nantinya sesuai perlakuan.

\section{Proses Pembuatan Edible Coating Pati Biji Buah Alpukat}

Masak pati biji buah alpukat sesuai perlakuan P1: 0\%, P2 : 5\%, P3 : $10 \%$, P4 : $15 \%$ dengan penambahan 100 $\mathrm{ml}$ aquades hingga mendidih (apikecil) pada suhu 750C selama 15 menit hingga tercampur rata. Tambahkan Gliserol 2\% dan aduk secara merata kemudian tambahkan ekstrak jahe sesuai perlakuan kemudian aduk rata.

Pindahkan larutan edible coating pati biji alpukat yang telah siap diaplikasikan dalam wadah steril, tunggu hingga sedikit dingin. Buah strawberry yang digunakan di timbang 10 gram terlebih dahulu berat awal nya kemudian catat. Aplikasikan buah strawberry dengan cara mencelupkan kedalam edible coating selama 2-3 menit hingga menutupi semua permukaan kulit buah strawberry timbang lagi buah strawberry. Kemudian dikering anginkan letakkan dalam wadah yang bisa membantu larutan cepat kering. Simpan dalam suhu ruang 27 - 29 0C selama 5 hari. Lakukan pengamatan parameter.

\section{Parameter Pengamatan}

Pengamatan dan analisa parameter meliputi Susut bobot, Total padatan Total Soluble Solid (TSS), Uji Vitamin C, Total Asam Tertitrasi, Uji Organoleptik Warna, Aroma dan Rasa.

\section{Susut Bobot}

Pengukuran susut bobot dilakukan untuk membandingkan selisih bobot sebelum penyimpanan dengan sesudah penyimpanan.

$$
\% \text { susut bobot }=\frac{\left(W_{0}-W_{t}\right)}{W_{0}}=100 \% \ldots .
$$

Keterangan :

$$
\begin{aligned}
& \text { Wo : Berat sampel awal (g) } \\
& \text { Wt : Berat sampel akhir (g) }
\end{aligned}
$$

\section{Total Soluble Solid (TSS)}

Pengukuran Tss menggunakan Hand Refractmeter (0-390 Brix). Sebelum digunakan alat dibersihkan terlebih dahulu dengan akohol dan dilap hingga kering. Sampel yang akan diukur kemudian diletakkan secukupnya pada tempat pembacaan. Tingkat kemanisan akan langsung dibaca pada alat.

\section{Uji Vitamin C}

Timbang 10 g Strawberry kemudian haluskan dengan mortal. Masukkan dalam erlenmaeyer kemudian tambahkan dengan aquades hingga volumenya $100 \mathrm{ml}$. Saring dengan kertas saring dalam beaker glass sebanyak $10 \mathrm{ml}$ tambahkan indicator amilum 2-3 tetes, kemudian titrasi dengan menggunakan larutan standar Iodium 0,1 N hingga warnanya berubah menjadi violet.

$$
\text { Vitamin } \mathrm{C}\left(\frac{\mathrm{mg}}{100 \mathrm{~g}}\right)=\frac{\mathrm{ml} \mathrm{lod} \times 0,88 \times \mathrm{FP} \times 100}{\text { Berat bahan }} \ldots \text { (2) }
$$

Keterangan :

Ml Iod : Volume Iodium (ml)

0,88 : Berat equivalen

FP : Faktor pengencer

Barat Bahan : Massa bahan (gram)

\section{Uji Total Asam Tertitrasi}

Timbang $10 \mathrm{~g}$ strawberry kemudian haluskan dengan mortal. Masukkan dalam erlenmaeyer kemudian 
Muhammad Fahmi Rangkuti, Muhammad Hafiz, Irma Julyanty Munthe, Misril Fuadi / Agrintech | Jurnal Teknologi Pangan dan Hasil Pertanian 3 (1) 2019, 1-10

tambahkan dengan aquades hingga volumenya $100 \mathrm{ml}$. Saring dengan kertas saring dalam beaker glass sebanyak $10 \mathrm{ml}$ tambahkan indicator amilum 2-3 tetes, kemudian titrasi dengan menggunakan larutan standar $\mathrm{NaOH} \quad 0,1 \mathrm{~N}$ hingga warnanya berubah menjadi pink permanen.

Total asam :

$$
\begin{aligned}
& \left(\frac{\mathrm{mg}}{100 \mathrm{~g}}\right)=\frac{\mathrm{ml} \mathrm{NaoH} \times \mathrm{n} \mathrm{NaoH} \times \text { B.M X FP }}{\text { Berat bahan X } 1000 \text { X Valensi }} \times 100 \% . \text { (3) } \\
& \text { Keterangan } \\
& \mathrm{Ml} \mathrm{NaOH} \quad \text { : Volume } \mathrm{NaOH}(\mathrm{ml}) \\
& \mathrm{nNaOH} \quad \text { : Nilai satu mol } \mathrm{NaOH} \\
& \text { FP : Faktor pengenceran }
\end{aligned}
$$

\section{Uji Organoeleptik Warna}

Uji organoleptik warna terhadap buah strawberry yang dilapisi edible coating pati biji buah alpukat 5 hari penyimpanan dilakukan dengan uji kesukaan atau uji hedonik. Pengujian dilakukan terhadap buah strawberry yang dilapisi edible coating pati biji buah alpukat setelah 5 hari penyimpanan yang dibagikan kepada panelis untuk diuji. Pengujian dilakukan dengan cara di coba oleh 10 orang panelis . Penilaian dilakukan berdasarkan skala hedonik dan skala numerik .

\section{Uji Organoeleptik Aroma}

Uji organoleptik aroma terhadap buah strawberry yang dilapisi edible coating pati biji buah alpukat 5 hari penyimpanan dilakukan dengan uji kesukaan atau uji hedonik. Pengujian dilakukan terhadap buah strawberry yang dilapisi edible coating pati biji buah alpukat setelah 5 hari penyimpanan yang dibagikan kepada panelis untuk diuji. Pengujian dilakukan dengan cara di coba oleh 10 orang panelis. Penilaian dilakukan berdasarkan skala hedonik dan skala numerik.

\section{Uji Organoeleptik Rasa}

Uji organoleptik rasa terhadap buah strawberry yang dilapisi edible coating pati biji buah alpukat 5 hari penyimpanan dilakukan dengan uji kesukaan atau uji hedonik. Pengujian dilakukan terhadap buah strawberry yang dilapisi edible coating pati biji buaha lpukat setelah 5 hari penyimpanan yang dibagikan kepada panelis untuk diuji. Pengujian dilakukan dengan cara di coba oleh 10 orang panelis. Penilaian dilakukan berdasarkan skala hedonik dan skala numerik.

\section{HASIL DAN PEMBAHASAN}

\section{Susut Bobot Pengaruh Jumlah Pati Biji Alpukat Dengan Susut Bobot}

\begin{tabular}{|c|c|c|c|c|c|c|}
\hline \multirow{2}{*}{ Jarak } & \multicolumn{2}{|c|}{ LSR } & \multirow{2}{*}{$\begin{array}{c}\text { Perlakuan } \\
\mathrm{T}\end{array}$} & \multirow{2}{*}{$\begin{array}{r}\text { Rataan } \\
(\%)\end{array}$} & \multicolumn{2}{|c|}{ Notasi } \\
\hline & 0,05 & 0,01 & & & 0,05 & 0,01 \\
\hline- & - & - & $\mathrm{P} 1=0 \%$ & 0,396 & $\bar{A}$ & $\bar{A}$ \\
\hline 2 & 0,006 & 0,008 & $\mathrm{P} 2=5 \%$ & 0,221 & B & B \\
\hline 3 & 0,006 & 0,009 & $P 3=10 \%$ & 0,162 & $\mathrm{C}$ & $\mathrm{C}$ \\
\hline 4 & 0,006 & 0,009 & $\mathrm{P} 4=15 \%$ & 0,094 & D & D \\
\hline
\end{tabular}

Pada tabel 9 dapat di lihat bahwa P1 berbeda sangat nyata dengan P2, P3 dan P4. P2 berbeda sangat nyata dengan P3 dan P4. P3 berbeda sangat nyata dengan $\mathrm{P} 4$.

Tabel 9. Hasil Uji Beda Rata- Rata penaruh jumlah pati biji alpukat dengan usut bobot strawberry

Keterangan : Huruf yang berbeda pada kolom notasi menunjukkan pengaruh yang berbeda nyata pada taraf $(\mathrm{p}<5 \%)$ dan berbeda sangat nyata pada taraf $(\mathrm{p}<1 \%)$.

Susut bobot tertinggi terdapat pada perlakuan P1 sebesar 0,396\% dan terendah P4 sebesar 0,094\% untuk lebih jelasnya dapat dilihat pada gambar 4 .

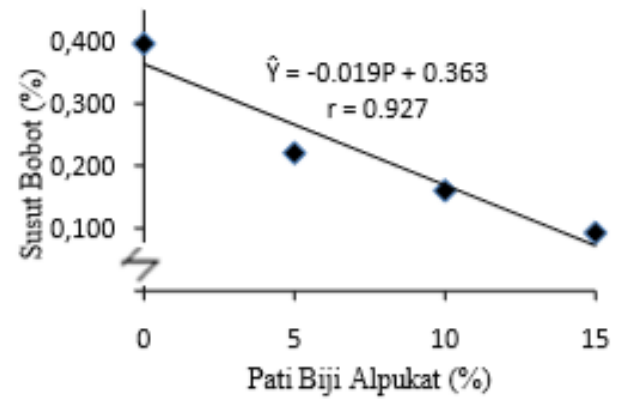

Gambar 4. Hubungan jumlah pati piji alpukat dengan susut bobot strawberry

Pada gambar 4 dapat dilihat bahwa semakin tinggi jumlah pati maka susut bobot semakin menurun. Hal ini membuktikan bahwa aplikasi edible coating berperan sebagai berier terhadap gas (CO2 dan 02) dan uap air sehingga dapat memperkecil laju respirasi dan transpirasi buah strawberry Wills, dkk (1981) menyatakan bahwa selama 
Muhammad Fahmi Rangkuti, Muhammad Hafiz, Irma Julyanty Munthe, Misril Fuadi / Agrintech | Jurnal Teknologi Pangan dan Hasil Pertanian 3 (1) 2019, 1-10

penyimpanan, produk mengalami proses respirasi dan traspirasi sehingga senyawa-senyawa kompleks yang terdapat didalam sel seperti karbohidrat dipecah menjadi molekul-molekul sederhana seperti $\mathrm{CO} 2$ dan $\mathrm{H} 2 \mathrm{O}$ yang mudah menguap. Penguapan komponenkomponen yang terkandung dalam buah menyebabkan buah mengalami pengurangan bobot atau susut bobot .

Selain di karenakan traspirasi dan respirasi, susut bobot juga disebabkan oleh karbohidrat dan bahan organik dalam kulit yang pada pemasakan diubah menjadi zat pati sehingga sedikit demi sedikit terjadi pengurangan berat pada kulit (Hartuti, 2006)

\section{Hubungan Penambahan Ekstrak Jahe} Dari Tabel 10 dapat dilihat bahwa D1 berbeda sangat nyata dengan D2, D3 dan D4. 4D2 berbeda sangat nyata dengan D3 dan D4. D3 berbeda sangat nyata dengan $\mathrm{D} 4$

Tabel 10. Hasil Uji Beda Rata-Rata pengaruh Penambaha Esktrak Jahe Dengan Susut Bobot Strawberry.

\begin{tabular}{ccccccc}
\hline \multirow{2}{*}{ Jarak } & \multicolumn{2}{c}{ LSR } & Perlakuan & Rataan & \multicolumn{2}{c}{ Notasi } \\
\cline { 2 - 3 } \cline { 6 - 7 } & 0,05 & 0,01 & $\mathrm{G}$ & $(\%)$ & 0,05 & 0,01 \\
\hline- & - & - & $\mathrm{D} 1=0 \%$ & 0,270 & $\mathrm{~A}$ & $\mathrm{~A}$ \\
2 & 0,006 & 0,008 & $\mathrm{D} 2=3 \%$ & 0,211 & $\mathrm{~B}$ & $\mathrm{~B}$ \\
3 & 0,006 & 0,009 & $\mathrm{D} 3=6 \%$ & 0,203 & $\mathrm{C}$ & $\mathrm{C}$ \\
4 & 0,006 & 0,009 & $\mathrm{D} 4=9 \%$ & 0,189 & $\mathrm{D}$ & $\mathrm{D}$ \\
\hline
\end{tabular}

Keterangan : Huruf yang berbeda pada kolom notasi menunjukkan pengaruh yang berbeda nyata pada taraf $(\mathrm{p}<5 \%)$ dan berbeda sangat nyata pada taraf $(\mathrm{p}<1 \%)$

Susut bobot tertinggi terdapat pada perlakuan D1 sebesar 0,270 \% dan terendah D4 sebesar 0,189 \%. Lebih jelasnya dapat dilihat pada gambar 5 .

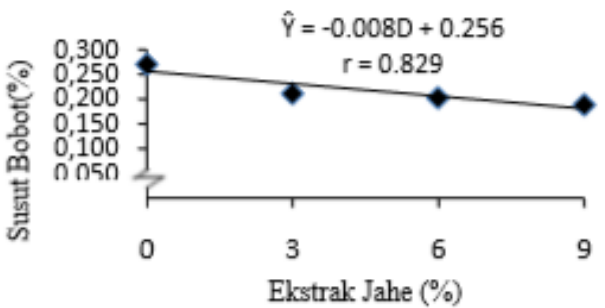

Gambar 5. Hubungan Penambahan Ekstrak Jahe Dengan Susut Bobot Strawberry

Pada gambar 5 dapat dilihat bahwa semakin tinggi penambahan ekstrak daun sirih maka susut bobot akan semakin menurun. Hal ini di karenakan penambahan ekstrak jahe yang berfungsi sebagai bahan antimikroba membantu mencegah kerusakan Strawberry yang telah dilapisi dengan edible coating.

Penambahan ekstrak jahe membuat edible coating semakin bertahan lama dan mampu memperpanjang masa simpan stawberry karena merupakan duble proktaktion dalam membantu mencegah traspirasi atau penguapan air dari bahan yang menyebabkan kehilangan susut bobot buah semakin sedikit. Komponen anti mikroba digunakan untuk menghambat aktifitas mikrobia dengan cara mengganggu komponen penyusun dinding sel, bereaksi dengan membran sel sehingga meningkatkan permebilitas dan menyebabkan kehilangan komponen penyusun sel, dan menonaktifkan ezim esensial (Burt, 2004).

\section{Hubungan Interaksi Antara Pati Biji Alpukat dan Ekstrak Jahe Dengan Susut Bobot.}

Hubungan interaksi penambahan jumlah pati biji alpukat dan ekstrak Jahe terhadap susut bobot dapat dilihat (gambar 6).

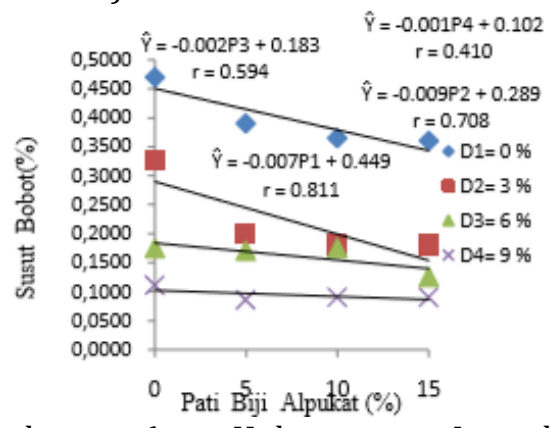

Gambar 6. Hubungan Interaksi Penambahan Jumlah Pati Biji Alpukat dan Penambahan Ekstrak Jahe Dengan Susut Bobot Strawberi.

Dari Gambar 6 dapat dilihat bahwa interaksi antara jumlah pati biji alpukat dan jumlah penambahan ekstrak jahe mengalami penurunan. Susut bobot tertinggi terdapat perlakuan P1D1. Semakin lama penyimpanan membuat edible coating mampu mempertahankan susut bobot yang dapat merusak bahan terkhusus nya pada buah strawberry karena daya kemampuan edible coating untuk melapisi permukaan buah strawberry sangat bagus dan memperlambat laju respirasi. Pada 
perlakuan penambahan pati biji alpukat $0 \%$ dengan konsentrasi terendah (kontrol) dengan penambahan ekstrak pati biji alpukat $0 \%$ dan dengan tanpa penambahan kedua kosentrasi maka otomatis tidak di lapisi dengan edible coating oleh sebab itu laju respirasinya akan semangkin cepat dan mengakibatkan pembusukan juga semakin cepat karena memiliki kontak dengan udara. Interaksi penambahan pati biji alpukat dan ekstrak jahe mempengaruhi penurunan nilai susut bobot selama masa simpan.

Hal ini disebabkan semakin tinggi penambahan jumlah pati dan dengan penambahan gliserol sebanyak $2 \%$ membuat penyalut edible semakin baik dan dapat menutupi atau menyalut seluruh bagian luar dari buah strawberry, Sehingga membuat kontak dengan udara semakin kecil dan dengan adanya penambahan ekstrak jahe yang berfungsi sebagai edable proktektion yang menghambat kerusakan buah strawberry yang di akibatkan oleh mikroorganisme (Pantastico,1989).

\section{Vitamin C}

Pengaruh Jumlah Pati Biji Alpukat Daftar sidik ragam (Lampiran 3) dapat dilihat bahwa jumlah konsentrasi pati biji alpukat memberikan pengaruh berbeda sangat nyata $(\mathrm{p}<1 \%)$ terhadap vitamin $\mathrm{C}$. Tingkat perbedaan tersebut telah diuji dengan uji beda rata-rata dapat dilihat pada Tabel 14 .

Tabel 14. Hasil Uji Beda Rata-Rata Hubungan Jumlah Pati Biji Alpukat Dengan Vitamin C

\begin{tabular}{|c|c|c|c|c|c|c|c|}
\hline \multirow{2}{*}{ Jar } & \multirow{2}{*}{ Jarak } & \multicolumn{2}{|c|}{ LSR } & \multirow{2}{*}{$\begin{array}{c}\text { perlakuan } \\
\mathrm{T}\end{array}$} & \multirow{2}{*}{$\begin{array}{l}\text { Rataan } \\
(\%)\end{array}$} & \multicolumn{2}{|c|}{ Notasi } \\
\hline & & 0,05 & 0,01 & & & 0,05 & 0,01 \\
\hline - & - & - & - & $\mathrm{P} 1=0 \%$ & 9,833 & $\mathrm{D}$ & D \\
\hline 2 & 1 & 0,190 & 0,261 & $\mathrm{P} 2=5 \%$ & 12,311 & C & $\mathrm{C}$ \\
\hline 3 & 2 & 0,199 & 0,275 & $P 3=10 \%$ & 15,431 & B & B \\
\hline 4 & 3 & 0,204 & 0,282 & $P 4=15 \%$ & 19,566 & A & A \\
\hline
\end{tabular}

Keterangan : Hurup yang berbeda pada kolom notasi menunjukkan pengaruh yang berbeda nyata pada taraf $(\mathrm{p}<5 \%)$ dan berbeda sangat nyata pada taraf $(\mathrm{p}<1 \%)$.

Dari Tabel 14 dapat dilihat bahwa P1 berbeda sangat nyata dengan P2, P3 dan P4. P2 berbeda sangat nyata dengan P3 dan P4. P3 berbeda sangat nyata dengan $\mathrm{P} 4$. Vitamin $\mathrm{C}$ tertinggi terdapat pada perlakuan P4 sebesar
$19,566 \mathrm{mg} / 100 \mathrm{~g}$ dan terendah terdapat pada perlakuan P1 sebesar 9,833 mg/100 g . Lebih jelasnya dapat dilihat pada gambar 9 .

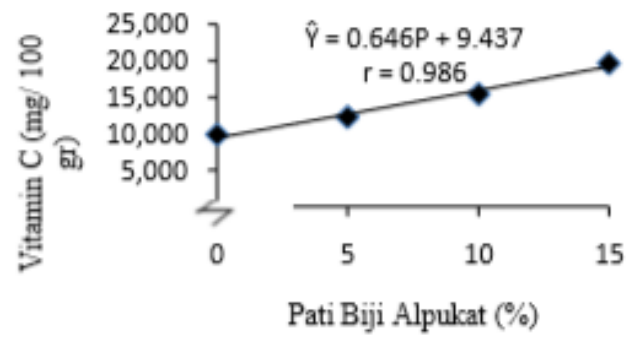

Gambar 9. Hubungan Jumlah Pati Biji Alpukat Dengan Vitamin C

Buah merupakan sumber utama vitamin dan mineral salah satu vitamin yang dikandung buah- buahan adalah vitamin C. Oleh sebab itu kandungan yang terdapat pada strawberry yaitu salah satunya vitamin $\mathrm{C}$ dapat di pertahankan selama 5 hari penyimpanan hal ini dapat dilihat pada Gambar 9 bahwa semakin tinggi jumlah konsentrasi pati biji alpukat maka vitamin C semakin dapat di pertahankan. Pati yang ditambahakan dalam pembuatan ediblecoating pati biji alpukat semakin tinggi maka semakin dapat melapisi permukaan kulit buah dengan baik yang membuat kontak dengan udara atau oksigen semakin berkurang.

Hal ini membuat Vitamin C yang dapat rusak karena adanya oksidasi dapat dikurangi dengan adanya pelapisan edible coating tersebut. Kenaikan vitamin C buah strawberry setelah dilapisi edible coating Selama penyimpanan kandungan vitamin C buah strawberry dapat dipertahankan setiap harinya, karena dengan pelapisan edible coating dengan bahan dasar pati biji alpukat dengan penambahan ekstrak jahe maka buah strawberry dapat diperpanjang masa simpannya, dan dengan demikian edible coating juga dapat menghambat terjadinya respirasi ataupun penguapan gas yang dapat mengurangi kandungan-kandungan yang terdapat pada strawberry. Selain itu edible coating juga membantu terjadinya proses biosintesis vitamin $\mathrm{C}$ dari glukosa yang terdapat pada buah (Googman,1996 dalam Kartika, 2012). 
Muhammad Fahmi Rangkuti, Muhammad Hafiz, Irma Julyanty Munthe, Misril Fuadi / Agrintech | Jurnal Teknologi Pangan dan Hasil Pertanian 3 (1) 2019, 1-10

Pengaruh Penambahan Ekstrak Jahe

Daftar sidik ragam (Lampiran 3) dapat dilihat bahwa jumlah ekstrak jahe memberikan pengaruh berbeda sangat nyata $(\mathrm{p}<1 \%)$ terhadap vitamin $\mathrm{C}$. Tingkat perbedaan tersebut telah diuji dengan uji beda rata-rata dapat dilihat pada Tabel 15.

Tabel 15. Hasil Uji Beda Rata-Rata Hubungan Penambahan Ekstrak Jahe Dengan Vitamin

\begin{tabular}{rccccccc}
\hline \multirow{2}{*}{ Jarak } & \multicolumn{2}{c}{ LSR } & Perlakuan & Rataan & \multicolumn{2}{c}{ Notasi } \\
\cline { 2 - 3 } \cline { 6 - 7 } & 0,05 & 0,01 & G & $(\%)$ & 0,05 & 0,01 \\
\hline- & - & - & D1 $=0 \%$ & 12,774 & d & D \\
2 & 0,190 & 0,261 & D2 $=3 \%$ & 13,964 & c & C \\
3 & 0,199 & 0,275 & D3 $=6 \%$ & 14,798 & b & B \\
4 & 0,204 & 0,282 & D4=9\% & 15,606 & a & A \\
\hline
\end{tabular}

Keterangan : Hurup yang berbeda pada kolom notasi menunjukkan pengaruh yang berbeda nyata pada taraf $(\mathrm{p}<5 \%)$ dan berbeda sangat nyata pada taraf $(\mathrm{p}<1 \%)$.

Di Tabel 15 dapat di lihat bahwa D1 berbeda sangat nyata dengan D2, D3 dan D4. D2 berbeda sangat nyata dengan D3 dan D4. P3 berbeda sangat nyata dengan D4. Vitamin C tertinggi terdapat pada perlakuan D4 sebesar 15,606 $\mathrm{mg} / 100 \mathrm{~g}$ dan terendah P1 sebesar $12,774 \mathrm{mg} / 100$ g.untuk lebih jelasnya dapat dilihat pada gambar 8 .

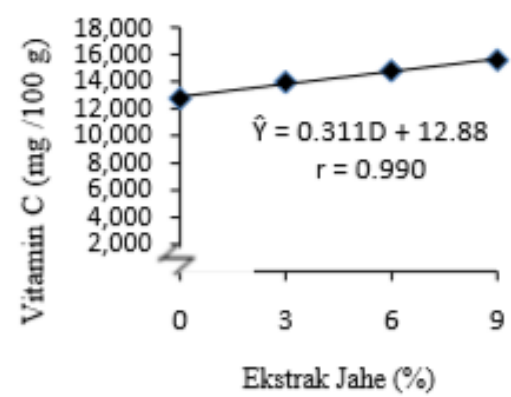

Gambar 10. Hubungan Penambahan Ekstrak Jahe dengan Vitamin C

Dari Gambar 10 dapat dilihat bahwa semakin tinggi penambahan ekstrak jahe maka vitamin $\mathrm{C}$ dapat di pertahankan. Berdasarkan Rosman Suherman (2006), kandungan vitamin $C$ pada ekstrak jahe sekitar $5 \mathrm{mg} / 100 \mathrm{~g}$.

Hal ini memberikan pengaruh terhadap mempertahankan vitamin C buah strawberry selama penyimpanan. Peningkatan kadar vitamin C terjadi karena buah strawberry yang dilapisi edible dengan penambahan ekstrak jahe dan konsentrasi yang tinggi maka akan lebih sedikit kehilangan air sehingga kandungan vitamin C dapat dipertahankan (Balwin, 2003).

Menurut Winarno (1997), asam askorbat merupakan vitamin yang larut air yang dapat berbentuk sebagai asam askorbat. Menurut Winarno (1993), asam askorbat sangat mudah teroksidasi menjadi asam dalamair yang bersifat labil dan dapat mengalami perubahan lebih lanjut menjadi asam yang tidak memiliki keikatan vitamin C. Selain itu pada saat pembuatan pati biji alpukat direndam dalam asam sitrat yang berfungsi sebagai antioksidan , sehingga pada kerusakan vitamin C akibat oksidasi dapat diminimalisir. Penambahan ekstrak jahe yang berfungsi sebagai bahan antimikroba juga ikut berperan dalam meningkatkan vitamin $\mathrm{C}$ buah strawberry setelah dilapisi edible coating pati biji alpukat karena selain dapa menghabat mikroba yang akan merusak bahan selama penyimpanan

Hubungan Interaksi Antara Jumlah Pati Biji Alpukat dan Penambahan Ekstrak Jahe Dengan Vitamin C

Nilai rataan tertinggi yaitu pada penambahan jumlah pati biji alpukat yaitu 15\% (P4) dan penambahan ekstrak jahe $9 \%$ (D4) yaitu $21,130 \%$ dan nilai rata-rata terendah yaitu pada penambahan jumlah pati biji alpukat $0 \%$ (P1) dan jumlah ekstrak jahe $0 \%$ (D1) yaitu 7,925\%. Hubungan interaksi jumlah pati biji alpukat dan ekstrak jahe terhadap Vitamin C dapat dilihat pada gambar 11.

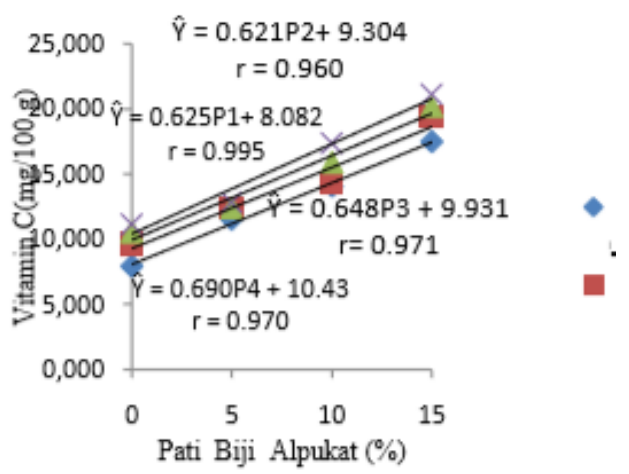

Gambar 11. Hubungan Interaksi Jumlah Pati Biji Alpukat dan Penambahan Ekstrak jahe Dengan Vitamin C 
Muhammad Fahmi Rangkuti, Muhammad Hafiz, Irma Julyanty Munthe, Misril Fuadi / Agrintech | Jurnal Teknologi Pangan dan Hasil Pertanian 3 (1) 2019, 1-10

bahwa interakasi jumlah konsentrasi pati biji alpukat dan penambahan ekstrak jahe terhadap vitamin C semakin dapat di pertahankan.

Nilai rataan tertinggi terdapat pada perlakuan P4D4 yaitu 21,130 mg/100 g dan kosentrasi tertinggi pati biji alpukat $15 \%$ yang mampu melapisi permukaan buah dengan baik sehingga mampu mengurangi kontak dengan oksigen sehingga mampu mengurangi kehilangan vitamin $\mathrm{C}$ serta dengan penambahan ekstrak jahe $9 \%$ yang mampu menambah nilai kandungan gizi vitamin $\mathrm{C}$ selama penyimpanan dan juga dengan penambahan gliserol sebanyak $2 \%$ juga membantu untuk lebih bagus dalam pelapisan edible coating pada buah strawberry.

Sedangkan perlakuan terendah terdapat dalam perlakuan P1D1 yaitu 7,925 mg/100 g dimana hal ini yang menyebabkan banyak terjadinya penurunan vitamin $\mathrm{C}$ karena jumlah penambahan pati biji alpukat $0 \%$ dan jumlah penambahan ekstrak jahe $0 \%$. Hal ini juga dikarenakan buah strawberry yang digunakan dalam pengaplikasian edible coating pati biji alpukat semakin tua dengan seiring dengan lama penyimpanan. Hal ini di karenakan buah strawberry termasuk buah non klimaterik dimana laju respirasinya tetap semakin berjalan dari saat pascapanen itu juga yang menyebabkan nilai kandungan vitamin $\mathrm{C}$ meningkat.

\section{Total AsamTertitrasi}

Pada jumlah pati biji alpukat memberikan pengaruh berbeda sangat nyata $(\mathrm{p}<1 \%)$ terhadap total asam (tabel 7)

Tabel 17. Tabel 17. Hasil Uji Rata-Rata Hubungan Jumlah Pati Biji Alpukat Dengan Total Asam

\begin{tabular}{|c|c|c|c|c|c|c|}
\hline \multirow[b]{2}{*}{ Jarak } & \multicolumn{2}{|c|}{ LSR } & \multirow{2}{*}{$\begin{array}{c}\text { Perlakuan } \\
\text { T }\end{array}$} & \multirow{2}{*}{$\begin{array}{c}\text { Rataan } \\
(\%)\end{array}$} & \multicolumn{2}{|c|}{ Notasi } \\
\hline & 0,05 & 0,01 & & & 0,05 & $\begin{array}{l}0,0 \\
1\end{array}$ \\
\hline - & - & - & $P 1=0 \%$ & 0,434 & D & D \\
\hline 2 & 0,075 & 0,104 & $P 2=5 \%$ & 0,748 & $\mathrm{C}$ & $\mathrm{C}$ \\
\hline 3 & 0,079 & 0,109 & P3 $=10 \%$ & 1,136 & B & B \\
\hline 4 & 0,081 & 0,112 & $\mathrm{P} 4=15 \%$ & 1,681 & A & A \\
\hline
\end{tabular}

Ketengan : Huruf yang berbeda pada kolom notasi menunjukkan pengaruh yang berbeda nyata pada taraf $(\mathrm{p}<5 \%)$ $(\mathrm{p}<1 \%)$

Dari tabel 17 dapat dilihat bahwa P1 berbeda sangat nyata dengan P2, P3 dan P4. P2 berbeda sangat nyata dengan P3 dan P4.P3 berbeda sangat nyata dengan P4. Total asam tertinggi terdapat pada perlakuan P4sebesar 1,681\% dan terendah terdapat pada perlakuan P1 sebesar $0,434 \%$. Lebih jelasnya dapat dilihat pada gambar 12

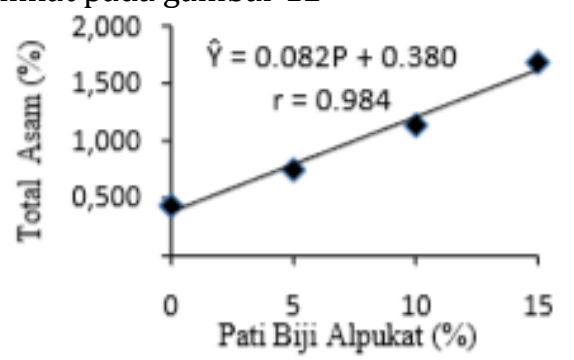

Gambar 12. Hubungan Jumlah Pati Biji Alpukat Dengan Total Asam

Dari Gambar 12 dapat dilihat bahwa semakin tinggi jumlah pati biji alpukat maka total asam akan semakin meningkat. Hal ini disebabkan karena semakin tinngi jumlah yang ditambahkan maka akan semakin meningkat kandungankandungan yang terdapat di buah strawberry seperti karbohidrat . Menurut Winarti dkk (2012), pelapisan edible coating dari pati biji alpukat dapat berperan sebagai membran permeable yang selektif terhadap pertukaran gas C02 dan 02. Dengan konsentrasi pati yang semakin tinggi maka edible coating yang di aplikasikan pada buah strawberry akan melapisi semua permukaan buah dengan merata oleh sebab itu kontak udara dengan udara akan semakin berkurang.

Hal ini juga di duga bahwasanya
pada umumnya buah strawberry
merupakan buah non klimaterik yang
akan terus mengalami respirasi atau pun
pernapasan, pada buah strawberry
respirasi yang terjadi yaitu respirasi
anaerob respirasi ini tidak memerlukan
oksigen atau 02. Respirasi anaerob terjadi
di bagian sitoplasma dan menghasilkan
energi yang lebih kecil yaitu 2 ATP
respirasi anaerob glukosa di pecah secara
tidak sempurna menjadi komponen H20
dan CO2 dan respirasi ini bergabung
bersama sejumlah komponen yaitu asam
Piruvat, yang selanjutnya membentuk


Muhammad Fahmi Rangkuti, Muhammad Hafiz, Irma Julyanty Munthe, Misril Fuadi / Agrintech | Jurnal Teknologi Pangan dan Hasil Pertanian 3 (1) 2019, 1-10

asam laktat dan etanol hal tersebut diduga salah satu penyebab terjadinya kenaikan pada total asam (Winarti, dkk , 2012).

Hubungan Interaksi Antara Jumlah Pati Biji Alpukat dan Penambahan Ekstrak Jahe Dengan Total Asam

Hubungan interaksi penambahan jumlah pati biji alpukat dan ekstrak jahe terhadap total asam dapat dilihat pada gambar 14 .

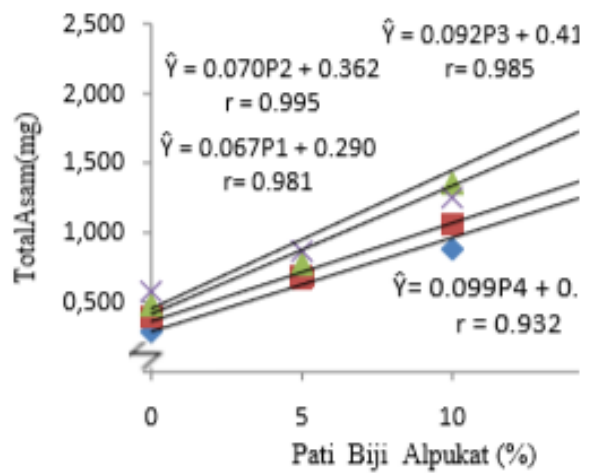

Gambar 14. Gambar Hubungan Hubungan Interaksi Jumlah Pati Biji Alpukat dan Penambahan Ekstrak Jahe Dengan Total Asam

Perubahan total asam tertitrasi disebabkan oleh adanya perubahan kandungan asam-asam organik yang terkandung didalam bahan, perubahan total asam tertitrasi dapat dipengaruhi oleh penyimpanan, reaksi enzimatis dan perubahan mikrobiologis. Hal ini disebabkan karena tingginya presentase total asam tertitrasi pada buah strawberry dikarenakan edible coating merupakan media penghambat selektif terhadap 02 CO2 modifikasi pada lapisan luar dan memperlambat laju respirasi buah (Amal dkk, 2010). Sehingga aplikasi edible coating dapat memperlambat peningkatan total asam tertitrasi. Pada akhir penyimpanan mengalami peningkatan presentase total asam tertitrasi pada seluruh strawberry . Hasil penelitian Cordenunsi dkk (2003), juga menyatakan perubahan total asam tertitrasi selama penyimpanan dapat bergantung pada varietas buah,dimana tidak terdapat perubahan total asam tertitrasi selama penyimpanan strawberry namun terjadi peningkatan total asam tertitrasi untuk varietas tertentu.

\section{KESIMPULAN DAN SARAN}

Kesimpulan

1. Jumlah konsentrasi pati biji alpukat memberikan pengaruh yang berbeda sangat nyata taraf $\mathrm{p}$ $<0,01$ terhadap susut bobot, TSS (Total Soluble Solid), vitamin C, total asam, uji organoleptik warna dan uji organoleptik rasa. Sedangkan pada taraf ( $\mathrm{p}>0,05$ ) berbeda tidak nyata terhadap uji organoleptik aroma.

2. Jumlah penambahan ekstrak jahe memberikan pengaruh yang berbeda sangat nyata taraf $\mathrm{p}<$ 0,01 terhadap susut bobot, TSS (Total Soluble Solid), vitamin C, total asam, uji organoleptik warna dan uji organoleptik rasa. Sedangkan pada taraf ( $p>0,05)$ berbeda tidak nyata terhadap uji organoleptik aroma.

3. Interaksi jumlah konsentrasi pati biji alpukat dan penambahan ekstrak jahe memberikan pengaruh berbeda sangat nyata terhadap susut bobot, vitamin C dan total asam tertitrasi dan berbeda tidak nyata pada TSS (Total Soluble Solid), Uji organoleptik warna, uji organoleptik aroma dan uji organoleptik rasa.

4. Hasil penelitian terbaik pada susut bobot adalah P4D4 yaitu 0,0900\%, vitamin C yaitu P4D4 sebesar 21,130 mg/100 gr, dan total asam P4D4 sebesar 2,112\%. Saran

1. Perlu dilakukan penelitian lebih lanjut mengenai pembuatan edible coating pati biji alpukat degan variable perlakuan jumlah konsentrasi pati biji alpukat dan ekstrak jahe lebih baik lagi yang sesuai untuk edible coating.

2. Perlu diteliti lebih lanjut lagi mengenai edible coating pati biji alpukat dengan perbandingan lama dan suhu penyimpanan serta analisis uji mikroba supaya dapat mengetahui efektifitas edible coating pada buah strawberry.

3. Penelitian ini dapat dilanjutkan dengan variasi dan jenis bahan lainnya untuk mengetahui perlakuan terbaik yang dapat menghasilkan 
Muhammad Fahmi Rangkuti, Muhammad Hafiz, Irma Julyanty Munthe, Misril Fuadi / Agrintech | Jurnal Teknologi Pangan dan Hasil Pertanian 3 (1) 2019, 1-10

untuk memperpanjang masa simpan dari suatu bahan.

\section{DAFTAR PUSTAKA}

Amirudin, 2010. Transpormasi Brokoli (Brocilla) Dengan Top Icing . Jurnal Teknologi 1 : 4048

Balwin. 2003. Themorplastic Strach A Green Material For V Aruous Industries. Viley-VCH. German. PD 102

Burt.S, 2004. Essensial Oils Anti Bacterial Properties dan Protensial Aplication In Foods A Riview. Int L. J. Food Microbial 94 : 223-253

Googman. 1996 dalam Kartika. 2012. Improving Srawberry Fruit By Edible Coating As A Carrier of Tymol Or Calcium Cloride. J.Hort Sci dan Omamen Post 2.3 PD 88-95

Hartati, N. 2006. Pengamatan Buah Segar Pada Penyimpanan Tomat Dengan Pelapis Lilin Untuk Memperpanjang Masa Simpan.Balai Penelitian Tanaman Sayuran. Bandung. 906 Halaman

Krocht J.M E.A Balwin dan M. Misperos-Cerret, 2002. Edible Coating and Film To Improve Food Quality. CRC Press. LLC. PP. 379

Pantastico. 1989. Fisiologi Pasca Panen Penanganan dan Pemanfaatan Buah dan Sayuran Tropika dan Subtropika. Universitas Gajah Mada. Press. Yogyakarta Rosman dan Suherman, 2006. Jahe Tanaman Obat Yang Perlu Sentuhan Teknologi Budidaya. Warta Penelitian dan Pengembangan Tanaman Industri Vol $121: 13-15$

Winarti dan Purnomo,2006. Olahan Biji Buah Alpukat. Trubus Agrisarana. Surabaya 